\title{
PRINSIP-PRINSIP PENGGEMBALAAN BERDASARKAN INJIL YOHANES 10:1-21
}

\author{
Alferdi \\ Institut Agama Kristen Negeri Toraja
}

\begin{abstract}
The purpose of this study is to give understanding to church pastors regarding the principles that must be held in serving. When a leader in the congregation does not have principles, this will have an impact on a leadership crisis in the Church. This article discusses what the principles of a church pastor are based on the text of the Gospel of John 10:1-21. An understanding of the principles of a pastor, of course, will be an advantage that in that way the ministry in the church will run well. The writing of this article uses a qualitative approach with a literature review. This approach tries to analyze the text of the Gospel of John 10:1-21 with various sources from books and online journals. This research shows that in the Gospel of John there are several principles of a shepherd, namely, shepherding is a calling, nurturing, and sacrifice. These three things must be interpreted well as a shepherd, so that the ministry is oriented to the growth of the congregation from various aspects, not a pastoral ministry that is only selfish or only looking for profit.
\end{abstract}

Keywords: shepherd, vocation, care, sacrifice

\begin{abstract}
Abstrak
Tujuan penulisan artikel ini ialah untuk memberi pemahaman kepada gembala jemaat mengenai prinsip yang harus dipegang dalam melayani. Ketika seorang pemimpin dalam jemaat tidak memiliki prinsip, ini akan berdampak pada adanya krisis kepemimpinan dalam Gereja. Artikel ini membahas apa yang menjadi prinsip dari seorang gembala jemaat yang ditinjau berdasarkan teks Injil Yohanes 10:1-21. Pemahaman mengenai prinsip seorang gembala, tentu akan menjadi suatu keuntungan bahwa dengan jalan itu pelayanan dalam jemaat akan berjalan dengan baik. Penulisan artikel ini menggunakan pendekatan kualitatif dengan kajian kepustakaan. Pendekatan ini berusaha menganalisis teks Injil Yohanes 10:1-21 dengan berbagai sumber dari buku maupun jurnal-jurnal online. Dari penelitian ini menunjukkan bahwa dalam Injil Yohanes ada beberapa prinsip dari seorang gembala yaitu, penggembalaan adalah panggilan, pemeliharaan, dan pengorbanan. Ketiga hal ini harus dimaknai dengan baik sebagai gembala, sehingga pelayanan berorientasi pada pertumbuhan jemaat dari berbagai aspek bukan pelayanan penggembalaan yang hanya mementingkan diri sendiri ataupun hanya mencari keuntungan.
\end{abstract}

Katakunci : gembala, panggilan, pemeliharaan, pengorbanan 


\section{PENDAHULUAN}

Dalam suatu organisasi, tentu membutuhkan seorang pemimpin untuk mengarahkan ataupun membimbing sehingga organisasi berjalan dengan baik. Pemimpinlah yang menjadi faktor utama untuk mempengaruhi kinerja suatu organisasi. Dengan kata lain, pemimpin adalah seorang yang memiliki kemampuan mengarahkan dan memberi semangat atau motivasi. Pemimpin adalah sosok yang berusaha untuk memengaruhi pikiran, kebiasaan, keyakinan atau nilai-nilai dari orang lain (Wrigth, 2000). Begitu juga dalam gereja, memiliki seorang pemipin yang biasa disebut gembala atau pendeta. (Kosta \& Djadi, 2011, p. 175)

Peran seorang gembala dalam jemaat sangat diperlukan untuk pertumbuhan jemaat. Maju mundurnya pertumbuhan rohani jemaat bergantung pada mereka.(Sudomo, 2009, p. 18) Pertumbuhan jemaat dari aspek rohani, tidak dapat dipungkiri mengalami kemerosotan karena ada berbagai faktor yang terjadi. Salah satu faktor yang menyebabkan hal tersebut karena dalam sebuah jemaat terjadi sebuah krisis kepemimpinan yang dialami oleh gembala jemaat. Krisis ini tentu sangat berpengaruh karena jemaat tidak memiliki keteladanan yang baik untuk mendorong pertumbuhan ke arah yang baik.

Kebanyakan yang terjadi saat sekarang ini di mana banyak gembala jemaat yang justru berselisih dengan jemaatnya, sehingga banyak anggota jemaat yang kemudian memilih meninggalkan Yesus karena tekanan-tekanan yang dialami. Di samping itu, anggota jemaat yang masih bertahan mulai hidup menurut apa yang mereka inginkan, bukan lagi apa yang Tuhan kehendaki dalam diri mereka. Begitu juga dengan para gembala, mereka kemudian hanya membiarkan hal-hal ini terjadi tanpa adanya sebuah kesadaran bahwa hal ini merupakan imbas dari kepemimpinan yang tidak baik.

Perlu diketahui bahwa sebagai seorang gembala ataupun pendeta dalam jemaat harus menyadari bahwa jemaat yang dilayani adalah milik Tuhan. Gembala harus memiliki orientasi pelayanan pada pertumbuhan jemaat, bukan pada hal-hal materi saja. Artinya bahwa dengan menyadari bahwa anggota jemaat adalah milik Tuhan yang memerlukan suatu bimbingan, maka hendaknya pemimpin atau gembala jemaat tidak berorientasi untuk mencari nama ataupun keuntungan dalam pelayanan, tetapi 
betul-betul melaksanakannya sesuai dengan kehendak Tuhan. (Tanihardjo, 2015, p. 3) Dengan demikian terjadi sebuah perubahan yang signifikan dalam pelayanan penggembalaan.

Keberhasilan seorang gembala memimpin dombanya tidak terlepas dari pemahamannya mengenai apa yang dikerjakan. Dengan kata lain bahwa seorang gembala dalam suatu jemaat mengerti betul apa yang menjadi prinsip seorang gembala dalam melayani. Prinsip ini yang kemudian dipegang teguh sehingga dalam melayani orientasinya jelas, bukan pada hal-hal yang hanya menguntungkan pribadi. Seorang gembala harus memiliki prinsip karena hal ini yang akan menuntun mereka melaksanakan amanat Tuhan, untuk kemajuan dan pertumbuhan jemaat yang lebih baik. Pemimpin dalam jemaat yang memiliki prinsip kepemimpinan yang sesuai dengan Firman Tuhan akan memiliki kualitas yang baik, karena sumber kepemipinannya berasal dari Roh Kudus.(Sudomo, 2009, p. 45)

Penulisan artikel ini bertujuan untuk memberikan pemahaman kepada setiap gembala/pendeta dalam jemaat tentang prinsip-prinsip penggembalaan yang ditinjau dari Injil Yohanes 10:1-21. Memahami prinsip penggembalaan akan menolong setiap gembala jemaat dalam mengemban tugas pelayanan. Karena dengan adanya prinsip yang dimiliki seorang gembala, maka pelayanan jemaat tentunya akan berpusat pada pertumbuhan yang baik, dan sesuai dengan amanat Tuhan.

\section{METODE PENELITIAN}

Penulisan artikel ini menggunakan pendekatan kualitatif dengan memperoleh berbagai sumber melalui kajian pustaka.(Zaluchu, 2020) Penulis mengambil berbagai informasi berkaitan dengan artikel ini, dengan menelaah berbagai literatur baik dari buku, jurnal maupun sumber lainnya. Dengan metode ini akan diperoleh informasi yang komprehensip. Literature yang digunakan adalah buku atau jurnal yang berhubungan dengan hermeneutic ataupun kritik teks tentang Injil Yohanes.

\section{HASIL DAN PEMBAHASAN}

\section{Analisis Teks Yohanes 10:1-21}

Injil Yohanes 10:1-21, merupakan sebuah perumpamaan yang disampaikan oleh Yesus dan di dalamnya sudah tersirat apa yang menjadi inti pembelajarannya. 
Perumpamaan ini bukanlah perumpamaan biasa yang sering dijumpai dalam tiga Injil lainnya atau yang biasa disebut Injil Sinoptik. Perumpamaan ini adalah sebuah deskripsi mengenai kehidupan yang Yesus lihat di Palestina abad pertama.(Michael, 1989, p. 175) Yesus hidup di zaman di mana pekerjaan sebagai gembala adalah hal yang sering dijumpai.(Bons-Strom, 2019, p. 2) Dan memang ini adalah sebuah keunikan dari ajaranajaran yang Yesus sampaikan yang tidak terlepas dari kehidupan politik, sosial, ekonomi orang Israel pada waktu itu. Jadi tentu bukan lagi hal asing di kalangan Israel jika perumpamaan yang disampaikan oleh Yesus berbicara mengenai gembala. Apa yang Yesus sampaikan di sini mendapat respon dari para pendengarnya (ayat 21).

Jika kembali melihat apa yang terjadi di pasal sebelumnya (pasal 9), maka kita akan menemukan alasan Yesus kemudian menyampaikan perumpamaan ini. Yesus yang pada waktu itu menyembuhkan seorang yang buta sejak lahirnya mendapat respon yang berbeda-beda dari orang Farisi. Tentu Yesus merasa bahwa tindakan-tindakan yang dilakukan oleh orang Farisi berawal dari ketidaktahuan mereka akan jati diri-Nya. Sehingga perumpamaan mengenai Gembala yang baik disampaikan-Nya. Perumpamaan ini tidak lain merujuk kepada Yesus sendiri. Jadi, keterkaitan antara pasal 9 dan 10 sudah sangat jelas, di mana pasal 9 sendiri merupakan latar belakang munculnya perumpamaan Yesus itu. Di pasal 9:41, berisi teguran Yesus yang sangat keras akan sikap orang Farisi yang masih dibutahkan oleh berbagai bentuk prasangkaprasangka.(Johnson, 1999, p. 157)

Perumpamaan mengenai Gembala yang baik mau memberikan sebuah pelajaran berharga bahwa meskipun Yesus berasal dari golongan kecil tetapi Dia mampu menjadi Gembala yang sejati.(Kruse, 2003, p. 229) Yesus mau memperlihatkan bagaimana seorang Gembala yang baik memperlakukan domba-dombanya dengan baik pula.(Tenney, 1996, p. 157) Ditinjau dari struktur teks, perumpamaan ini terbagi ke dalam dua bagian besar. Pada pasal 10:1-6 merupakan perumpamaan yang disampaikan oleh Yesus mengenai Gembala, dan di pasal 10:7-21 merupakan isi dari perumpamaan tersebut. 


\section{Perumpaan Yesus Mengenai Gembala (Yohanes 10:1-6)}

Dalam perumpamaan ini Yesus membandingkan dua sosok Gembala, di mana Gembala yang pertama digambarkan sebagai seorang pencuri. Gembala yang disebutkan sebagai seorang pencuri ini karena pada dasarnya ketika memasuki sebuah kandang ia tidak melalui pintu (memanjat tembok). Dalam ayat 2 yang menyebutkan mengenai pintu, tersirat bahwa perkataan ini mau mengajak melalui pintu (panggilan). Bahkan tersirat dalam perkataan Yesus yang menganggap dia sebagai seorang pencuri/perampok bahwa dia sebenarnya tidak layak disebutkan sebagai seorang gembala. Kemudian Gembala yang kedua adalah Gembala yang masuk melalui pintu dan akan menuntun domba-dombanya. Karena dia adalah seorang Gembala tentu domba-dombanya juga akan mengikutinya karena dombanya mengenal dia.

Henry dan Richard mengatakan bahwa perumpamaan Yesus ini bukan bagaimana mau mengajarkan tentang seorang Gembala memperlakukan dombanya, tetapi lebih kepada sebuah teguran akan orang-orang yang selalu menganggap dirinya gembala,(Blackaby \& Richard, 2009, p. 174) tetapi tindakannya tidak mencerminkan hal tersebut. Teguran ini tentunya mengarah kepada orang-orang Farisi pada waktu itu yang selalu menentang ajaran-ajaran Yesus. Bahkan Yesus juga pernah mengecam mereka dengan mengatakan bahwa bagaimana mungkin orang buta menuntun orang buta. Hal ini Yesus sampaikan hanya mau menegaskan bahwa mereka bukanlah Gembala yang sesungguhnya.

Ketergantungan domba akan Gembala dapat dilihat ketika Gembala berjalan di depan dan domba-dombanya mengikutinya dari belakang. Adanya ketergantungan ini mau menegaskan bahwa ketika Gembala itu akrab dan mampu beradaptasi dengan dombanya tentu domba tidak akan ragu mengikutinya. Inilah yang Yesus mau perlihatkan juga kepada orang Farisi bahwa penolakan mereka tidak lebih karena orang Farisi tidak mengenalnya. Tentu Yesus juga mau menyingkapkan bahwa Gembala yang baik tentu akan menuntun dombanya ke tempat yang dibutuhkan oleh domba, sebagaimana yang diungkapkan oleh raja Daud (Maz. 23).

Kehadiran orang jahat di tengah-tengah domba akan membawa sebuah masalah besar, yang bisa saja mengancam kehidupan dari domba-domba tersebut. Di ayat pertama memberikan indikasi bahwa mereka ini adalah juga seorang gembala tetapi dengan maksud dan tujuan yang berbeda (mencuri domba). Namun, Morris menegaskan

5 | Prinsip-Prinsip Penggembalaan..., Alferdi

Jurnal Christian Humanioran | http://e-journal.iakntarutung.ac.id/index.php/humaniora 
bahwa apapun yang dilakukan oleh pencuri itu tidak akan berpengaruh terhadap domba, karena domba tentu mengenal suara Gembalanya (ayat 5),(Morris, 1995, p. 448) dan Whitarce juga menegaskan akan hal itu bahwa, respon domba terhadap gembala yang mereka kenal akan berbeda dengan respon mereka terhadap orang asing, hal ini pula berlaku bagi manusia bagaimana mereka merespon sesuatu yang dikenalnya.(Whitarce, 1999, p. 256)

Dari serentetan perumpamaan yang disampaikan oleh Yesus ini ternyata tidak dipahami oleh pendengarnya. Jelas dalam ayat 6 bahwa mereka tidak mengerti apa yang disampaikan oleh Yesus. Sehingga perlu bagi Yesus untuk kembali menguraikan apa yang menjadi makna dari ajarannya tersebut. Sebagai respon-Nya, Yesus kemudian menjelaskan maknanya (ayat 7-21) untuk membuat mereka mengerti. Jadi, perumpamaan yang Yesus sampaikan tidak berhenti di ayat 6, tetapi dilanjutkan dengan penjelasan yang panjang.

\section{Makna Perumpamaan Yesus (Yohanes 10:7-21)}

Perumpamaan Yesus ini dijelaskan dengan begitu terperinci dalam ayat selanjutnya (7-21). Dalam ayat 7-8, Yesus dengan tegas mengatakan bahwa Ia adalah pintu menuju ke domba-domba itu. Orang-orang yang datang sebelum Ia itulah yang Yesus gambarkan sebagai seorang pencuri. Sangat jelas apa yang disampaikan Yesus ini bahwa pintu yang dimaksudkan ialah diri-Nya sendiri. Untuk meyakinkan pendengarNya, Yesus kembali menegaskan (ayat 9) bahwa karena Ia adalah pintu, maka setiap orang yang masuk melalui Dia akan memperoleh apa yang dibutuhkan dalam hal ini yang disebutkan Yesus ialah rumput. Selanjutnya, Yesus menguraikan apa yang menjadi tujuan utama-Nya. "Aku datang supaya mereka mempunya hidup," tentu sudah bisa kita pahami dari pengorbanan Yesus. Gambaran mengenai padang rumput adalah gambaran kehidupan yang nampak ketika mengikut Yesus.

Apa yang Yesus jelaskan mengenai siapa yang terdahulu sebelum Ia di sini tidak lain merujuk pada orang-orang Farisi yang menganggap diri taat terhadap hukum Taurat, dan juga mengajarkannya, tetapi tidak sesuai dengan kehidupan nyata mereka. Gembala yang Yesus inginkan di sini ialah mereka yang mampu menuntun ke jalan yang benar bukan mereka yang justru menimbulkan berbagai kekacauan. Dan Yesus sendiri sudah 
membuktikan bagaimana seorang Gembala terhadap kawanan domba-Nya. Yesus adalah Gembala juga ditegaskan oleh Bons-Strom dalam bukunya yang secara terperinci juga merujuk pada Yohanes 10.(Bons-Strom, 2019)

Penjelasan Yesus mengenai perumpamaan yang disampaikan berlanjut dengan penjelasan mengenai siapa Gembala yang dimaksudkan. Dalam ayat 11 Yesus dengan jelas menyebut diri-Nya adalah Gembala yang baik. Juga dalam ayat ini Yesus menjelaskan bagaimana Gembala terhadap kawananan dombanya yang rela memberikan nyawanya, dan Daniel Ronda menjelaskan bahwa ini adalah sebuah pengorbanan.(Ronda, 2011, p. 258) Berbeda dengan orang upahan atau yang bukan pemilik domba itu yang Yesus gambarkan sebagai seorang pencuri, begitu ada ancaman terhadap kawanan dombanya akan memilih untuk melindungi dirinya ketimbang dombadombanya. Ia tidak akan peduli masalah yang menimpa domba-dombanya, karena tidak memiliki rasa tanggung jawab terhadap dombanya.

Seorang Gembala yang baik tentu akan mengenal domba-dombanya, begitupun sebaliknya. Yesus juga menjelaskan akan hal ini bagaimana hubungan timbal balik yang terjadi antara Dia dan dombanya (manusia). begitupun hubungan antara Yesus dan Bapa yang saling mengenal. Yesus rela memberikan nyawa-Nya terhadap domba-domba-Nya yang menandahkan bahwa sebagai seorang Gembala Ia mau bekerja sampai lelah, waspada dan berani.(Bons-Strom, 2019) Dan itulah tugas Gembala yang sesungguhnya yang mau merawat dan menjaga domba-dombanya. Pengorbanan Yesus ini menurut Kruse merujuk pada tanggung jawab yang akan diemban oleh Yesus, di mana Dia mati untuk umat-Nya.(Kruse, 2003)

Di akhir penjelasan-Nya, Yesus menguraikan bagaimana tugas yang diberikan oleh Bapa kepada-Nya, dan bagaimana Ia menjalankan tugas itu. Pegangan utama yang Yesus terapkan ialah kasih, dan inilah yang mendasari pekerjaan-Nya sehingga sebagai seorang Gembala dia menjalankan-Nya dengan sukarela. Namun, kembali dalam ayat 19-21, Yesus lagi-lagi mendapat respon yang tidak baik dari pendengar-Nya. Bahkan orang-orang pada waktu itu menganggap Yesus kerasukan setan. Dan memang betul apa yang dikatakan Yesus sebelumnya bahwa mereka telah dibutahkan dengan prasangkaprasangka yang menyesatkan.

7 | Prinsip-Prinsip Penggembalaan..., Alferdi 


\section{Prinsip Penggembalaan Berdasarkan Yohanes 10:1-21}

Berbicara mengenai prinsip, berarti hal yang akan dibahas ialah apa yang menjadi asas atau pendirian dari seorang Gembala. Tentu prinsip yang dimaksudkan di sini ialah apa yang Injil Yohanes ungkapkan. Hal ini penting karena menyangkut bagaimana keberhasilan seorang Gembala dalam menata pelayanan ketika dia memiliki prinsip. Rasa tanggung jawab dari seorang Gembala akan muncul ketika dia memiliki prinsip, tentunya prinsip yang Alkitabiah. Berdasarkan Yohanes 10:1-21 maka ada beberapa prinsip yang harus dimiliki sebagai seorang Gembala.

\section{Penggembalaan adalah Sebuah Panggilan (ayat 2,7)}

Tentu akan menjadi sebuah pertanyaan mengapa dalam ayat 2 dan 7 ini kemudian disimpulkan bahwa penggembalaan itu adalah sebuah panggilan. Memang pada dasarnya dalam ayat tersebut tidak secara langsung menyebutkan akan hal tersebut. Tetapi, ketika ditelusuri dengan teliti akan ayat ini, di mana Yesus mengungkapkan mengenai pintu dan hal itu merujuk kepada diri-Nya, maka dapat disimpulkan bahwa di sini Yesus mengajak untuk datang melalui Dia. Ketika menyadari perkataan Yesus ini kesimpulan yang muncul bahwa penggembalaan itu adalah sebuah panggilan bukan atas dasar kemauan manusia semata. Meskipun menurut Lutzer di sisi lain kita sebagai manusia tentu sangat sulit menyadari akan kehendak Allah.(Lutzer, 2010, p. 8)

Memang sebagai seorang Gembala, tidak serta-merta menjalankan tugas tersebut, tetapi harus menyadarinya bahwa itu adalah sebuah panggilan. Panggilan di sini juga harus direspon sebagai wujud kesiapan memelihara umat-Nya.(Masweli \& Crider, 2002, p. 38) Itulah prinsip yang pertama yang seharusnya ada dalam diri Gembala untuk bisa membawa sebuah perubahan dalam jemaat, dan tentunya perubahan ini ialah perubahan ke arah yang lebih baik. Tugas penggembalaan adalah tanggung jawab yang diberikan oleh Allah dan harus dikerjakan sesuai dengan petunjuk dari Allah.(Rupa', 2016) Ketika hal ini tertanam maka tentunya pelayanan yang ada akan berjalan dengan baik pula.

Panggilan Allah menurut Sudibyo adalah sebuah kompetensi terbaik dalam pelayanan penggembalaan.(Sudibyo, 2019) Artinya bahwa ketika ada kesadaran dalam diri bahwa tugas penggembalaan adalah panggilan, maka tentu Dia akan memperlengkapi mereka yang terpanggil dengan berbagai kompetensi pelayanan. Orang 
yang merasa dirinya tidak terpanggil akan susah menyelesaikan berbagai permasalahan yang muncul di kalangan jemaat. Dan bahkan cenderung tidak lagi memeliharanya dengan baik. Panggilan penggembalaan memang merupakan sesuatu yang sulit untuk dijalani, tetapi hal itu bukan berarti ada penolakan di dalamnya. Menjalani panggilan dengan tekun akan membawa kita pada persoalan-persoalan yang Tuhan perlihatkan sebagai bagian dari ketaatan akan panggilan Tuhan.

\section{Penggembalaan Berbicara Mengenai Pemeliharaan (ayat 10)}

Ayat 10 dengan sangat jelas menekankan mengenai pemeliharaan. Jaminan kehidupan yang diperlihatkan Yesus dalam ayat ini mau memperlihatkan bagaimana tugas seorang Gembala dalam memelihara kawanan dombanya. Rice menegaskan bahwa sebagai seorang Gembala di tengah-tengah jemaat, harus menyadari tugas utamanya yaitu memelihara sehingga umat-Nya mampu pulih dari berbagai tekanan kehidupan yang ada.(Rice, 2006, p. 75) Tekanan kehidupan memang beragam dalam kalangan jemaat, baik itu dari segi ekonomi, sosial, dan bahkan segi politik. Jadi ketentraman dan kesejahteraan anggota jemaat tidak terlepas dari pemeliharaan seorang Gembala.

Kembali ditegaskan oleh Rice bahwa, dalam proses pemeliharaan Gembala terhadap jemaat, yang terpenting ialah bagaimana seorang Gembala mampu memelihara jiwa dengan melibatkan berbagai macam perhatian, karena dengan jalan itu menurutnya seorang Gembala mengurus bagaimana kawanan dombanya berhubungan dengan Allah dengan memfokuskan terhadap kehidupan rohani jemaat.(Rice, 2006) Namun, terlepas dari semua itu, menurut Bons-Strom hal ini tidak akan bisa dilakukan tanpa adanya hubungan yang intim antara jemaat dan Gembala. Olehnya itu perlu bagi seorang Gembala mengadakan sebuah perkunjungan pastoral, tentunya dengan teratur,(BonsStrom, 2019) sehingga terjadi interaksi yang baik antara gembala dan kawanan dombanya. Berkaitan dengan hal tersebut maka seharusnya seorang Gembala juga harus memperlengkapi dirinya dengan Firman Tuhan agar mampu memelihara kawanan dombanya dengan baik.

Tugas Gembala adalah memelihara, melindungi, membimbing dan menuntun kawanan dombanya. Meskipun kawanan domba berada pada masa-masa yang penuh bahaya dan ketidakpastian. Peran menuntun dan membimbing adalah gambaran pemeliharaan seorang Gembala yang bermanfaat mengingatkan kecenderungan di antara sejumlah analis yang melihat pelayanan sebagai gambaran yang agak pasif. Jadi di sisi

9 | Prinsip-Prinsip Penggembalaan..., Alferdi

Jurnal Christian Humanioran | http://e-journal.iakntarutung.ac.id/index.php/humaniora 
ini gembala dituntut untuk bertindak berani dan tegas, tetapi bukan berarti harus berbuat kasar.(D’Souza, 2009, p. 33) Bertindak tegas akan membuat kawanan domba tidak mempunyai cela untuk berbuat hal-hal yang menyimpang dari kehendak Allah.

Dalam rangka memelihara kawanan domba, seorang gembala harus sigap dari berbagai ancaman yang membahayakan domba. Sebagaimana keteladan yang diberikan oleh Yesus bahwa Ia adalah Gembala yang baik dan senantiasa memelihara dan menjaga manusia sebagai kawanan dombanya.(Tidbal, 1986, p. 218) Jadi sudah seharusnya gembala bertindak sesuai dengan keteladanan yang Yesus perlihatkan. Karena apa yang telah Yesus perlihatkan akan membuat seorang gembala juga mampu memelihara kawanan dombanya yaitu jemaat di mana dia melayani.

\section{Penggembalaan adalah Wujud Pengorbanan (ayat 11)}

Dalam ayat ini Yesus memperlihatkan Gembala yang rela berkorban demi kawanan domba-Nya. Seorang Gembala yang baik ialah mereka yang rela memberikan nyawanya kepada domba-dombanya, dan perkataan Yesus ini merujuk kepada apa yang akan dialaminya demi umat-Nya. Bagi Tidbal tentu ini adalah sebuah pengorbanan karena Yesus rela memberikan nyawanya dengan sukarela karena kasih. Olehnya itu dia menyimpulkan bahwa pelayanan penggembalaan itu berbicara mengenai pengorbanan, yaitu mengorbankan diri sendiri.(Tidbal, 1986, p. 99)

Donal Guthrie dalam bukunya, “Teologi Perjanjian Baru 2”, menyebutkan bahwa, Yesus memahami apa yang akan menghampirinya yaitu kematian. Tetapi karena sukarela yang dalam diri Yesus sehingga Ia laksanakan ini sebagai suatu keperluan kehendak Allah. Kematian Yesus ini dipandang sebagai kurban yang sangat istimewa dalam Perjanjian Baru.(Guthrie, 2019, p. 65) Melihat apa yang telah dilakukan Yesus, maka pada dasarnya Dia adalah Gembala yang baik itu, yang tidak memperhitungkan nyawa-Nya demi keselamatan domba-domba-Nya. Pengorbanan yang Dia lakukan tidak terlepas karena dia menyadari tugas-Nya sebagai Gembala.

Prinsip pengorbanan menjadi kunci suksesnya sebuah pelayanan penggembalaan yang dilakukan. Tanpa adanya prinsip ini Gembala tidak akan mampu menghidupi pelayanan yang dilakukannya. Karena sebagaimana yang dikatakan oleh Projogo bahwa memang pada dasarnya penggembalaan bukanlah hal yang mudah jika dinilai dari sisi 
kemanusiaan, tetapi membutuhkan banyak pengorbanan.(Prajogo, 2019) Pengorbanan itu bukan hanya mencakup pengorbanan nyawa sebagaimana yang diperlihatkan oleh Yesus, tetapi juga pengorbanan materi dan pikiran tentu sudah menjadi bagian di dalamnya. Pengorbanan terbesar seorang Gembala adalah mereka yang bisa menyediakan waktu meskipun dia menyadari ada begitu banyak hal lain yang harus diurus. Orang yang tidak bisa menyediakan waktu belum layak disebut sebagai seorang Gembala yang mampu berkorban.(Heward-Mills, 2015)

Dengan demikian, penghayatan akan ketiga prinsip ini akan membawa pada sebuah kesuksesan akan berjalannya sebuah pelayanan penggembalaan. Seorang Gembala harus memiliki prinsip agar bisa menjalankan tugasnya sesuai dengan kehendak Allah. Sehingga kerohanian jemaat juga dapat bertumbuh dengan baik karena Gembalanya hidup dengan prinsip yang Alkitabiah.

\section{KESIMPULAN}

Teks Injil Yohanes 10:1-21 terbagi ke dalam dua bagian besar di mana bagian yang pertama Yesus mengutarakan perumpamaan-Nya dan bagian kedua merupakan penjelasan Yesus mengenai makna perumpamaan-Nya. Di dalam perumpamaan yang disampaikan oleh Yesus, ada dua hal yang Yesus jelaskan, yaitu mengenai pintu dan mengenai Gembala. Pintu yang dimaksudkan Yesus di sini tidak lain merujuk pada diriNya dan mengenai Gembala, Gembala yang baik yaitu Yesus dan mereka yang dianggap sebagai Pencuri ialah orang-orang Farisi yang menganggap dirinya Gembala tetapi dalam kehidupannya ia sama saja dengan orang buta.

Perumpamaan yang disampaikan oleh Yesus ini mengandung prinsip yang harus dimiliki seorang Gembala saat ini. Ada tiga prinsip yang muncul di dalamnya, yaitu seorang Gembala harus menyadari bahwa penggembalaan adalah panggilan, gembala dalam menjalankan tugasnya harus memelihara umat-nya, dan juga penggembalaan itu berbicara mengenai pengorbanan. Ketiga hal ini harus dimiliki oleh Gembala untuk bisa membawa sebuah perubahan di dalam jemaat. Gembala yang memegang erat prinsip ini akan menyadari apa yang menjadi tanggung jawabnya di dalam jemaat. karena pada dasarnya kemajuan rohani jemaat tidak terlepas dari campur tangan Gembala dalam melaksanakan kehendak Allah.

11 | Prinsip-Prinsip Penggembalaan..., Alferdi

Jurnal Christian Humanioran | http://e-journal.iakntarutung.ac.id/index.php/humaniora 


\section{DAFTAR PUSTAKA}

Blackaby, H., \& Richard. (2009). Kepemimpinan Rohani. Gospel.

Bons-Strom, D. M. (2019). Apakah Penggembalaan Itu? PT BPK Gunung Mulia.

D’Souza, D. A. (2009). ENNOBLE, ENABLE, EMPOWER Kepemimpinan Yesus Sang Almasih. PT Gramedia Pustaka Utama.

Guthrie, D. (2019). Teologi Perjanjian Baru 2. PT BPK Gunung Mulia.

Heward-Mills, D. (2015). Apa Artinya Menjadi Seorang Gembala. Parchment House.

Johnson, B. W. (1999). John: The New Testament Commentary. Logos Research System, Ich, 3.

Kosta, Y., \& Djadi, J. (2011). Peranan Gembala Sebagai Pemimpin dalam Perspektif 1 Petrus 5:1-4 dan Relevansinya Pada Masa Kini. Jurnall Jaffaray, Vol. 9(2).

Kruse, C. G. (2003). John: An Introduction add Commentary. Inter-Varsity Press.

Lutzer, E. (2010). Pastor to Pastor. Gandum Mas.

Masweli, S., \& Crider, D. (2002). Gembala Sidang dan Pelayanannya. Kalam Hidup.

Michael, J. R. (1989). New Itnternational Biblical Commentary: John. Hendrickson Publisher.

Morris, L. (1995). The Gospel According to John. Erdmans Publishing Co.

Prajogo, N. S. (2019). Implementasi Kepemimpinan Gembala yang Melayani Berdasarkan 1 Petrus 5:2-10 di Kalangan Gembala Jemaat Gereja Bethel Indonesia Se-Jawa Tengah. Harvest: Jurnal Teologi Dan Kepemimpinan Kristen, Vol. 4(1), 1-21.

Rice, H. (2006). Manajemen Umat: Pendeta Sebagai Pengayom, Pemimpin, Pembina. Kalam Hidup.

Ronda, D. (2011). Leadership Wisdom: Antologi Hikmat Kepemimpinan. Kalam Hidup.

Rupa', C. S. (2016). Ciri Khas Seorang Gembala Berdasarkan Perspektif 1 Petrus 5:1-4. Jurnall Jaffaray, Vol. 14(2), 165-188.

Sudibyo, I. (2019). Pelayanan Kepemimpinan Penggembalaan Menurut Kisah Para Rasul 20:17-38. Jurnal Teologi Gracia Deo, Vol.2(1), 46-61.

Sudomo. (2009). Ciri Utama Kepemimpinan Sejati. ANDI.

Tanihardjo, P. B. (2015). Integritas Seorang Pemimpin Rohani. ANDI. 
Tenney, M. C. (1996). Injil Iman: Suatu Telaah Naskah Injil Yohanes Secara Analitis. Gandum Mas.

Tidbal, D. J. (1986). Skillful Shepherds. Inter-Varsity Press.

Whitarce, R. A. (1999). John. Inter-Varsity Press.

Wrigth, W. C. (2000). Relational Leadership A Biblical Model for Leadership Service. Paternoster Publishing.

Zaluchu, S. E. (2020). Strategi Penelitian Kualitatif dan Kuantitatif di Dalam Penelitian Agama. Evangelical: Jurnal Teologi Injili Dan Pembinaan Warga Jemaat, Vol. $4(1), 28-38$. 